\title{
PKMS JASA CUCI PAKAIAN RUMAHAN IBU RUMAH TANGGA DI KELURAHAN SEKIP JAYA, RT 21 RW 07 PALEMBANG SUMATERA SELATAN
}

\author{
Ery Hartati1), Usnia Wati Keristin²) \\ 1)Program Studi Komputerisasi Akuntansi, STMIK GI MDP \\ 2)Program Studi Akuntansi, STIE MDP \\ Jl. Rajawali No 14 Palembang, Kode pos 30113 \\ Email : ery hartati@mdp.ac.id ${ }^{11}$, tityn@stie-mdp.ac.id ${ }^{2}{ }^{2}$
}

\begin{abstract}
ABSTRAK
Kegiatan yang dilakukan oleh ibu-ibu rumah tangga yang bertujuan untuk membantu penghasilan keluarga dengan semangat emansipasi wanita mereka berjuang untuk membantu monopang kebutuhan keluarga. Beralamat di kelurahan sekip jaya, RT/RW 21/08, Palembang Sumatera Selatan. Salah satu tugas pokok Tri darma Perguruan tinggi adalah memberikan pengabdian kepada masyarakat. Oleh karena itu kami selaku dosen STMIK MDP ingin memberikan kontribusi kepada masyarakat agar dapat membantu mereka dalam mengembangkan usahanya terutama pada ibu-ibu rumah tangga dimana mereka bertujuan untuk meringankan beban kepala keluarga. Tujuan dari program PKMSS ini adalah untuk memberikan pemahaman, pembekalan, dan pelatihan kepada mitra dalam aspek produksi, pemasaran dan promosi usaha, permodalan, dan pembukuan usaha, agar usaha mereka dapat lebih berkembang dan memberikan penghasilan yang lebih baik. Target yang ingin dicapai adalah teratasinya masalah-masalah seperti : kapasitas produksi yang rendah, kualitas dan daya tahan produk.,. Sedangkan luaran yang diharapkan antara lain : pengadaan mesin cuci yang optimal, penampungan air bersih, adanya pembukuan usaha, adanya merek, kantong plastik, dan kartu nama sebagai atribut promosi. Agar tujuan, target, dan luaran dalam program PKMSS ini dapat direalisasikan dengan baik maka mekanisme pelaksanaan terdiri dari 4 tahap, yaitu persiapan dan perencanaan (sosialisasi dan penyusunan program), implementasi, evaluasi dan monitoring, dan refleksi. Semua tahapan dilakukan dengan metode partisipatif melalui teknik observasi, wawancara, FGD, dan pengambilan keputusan bersama.
\end{abstract}

Kata kunci : PKMSS, Jasa Cucian Pakaian, Pelatihan, Pemberdayaan Wanita

\section{PENDAHULUAN}

Pemberdayaan sumber daya manusia, khususnya peran wanita, memiliki adil yang cukup besar dalam membangun Negara, khusunya dalam membantu perekonomian keluarga. Peran wanita sangatlah penting, dan tugas meraka sangat berat selain menjadi ibu rumah tangga yang bertugas membantu mengurus keperluan keluarga dan juga harus membantu mencari nafkah keluarga setiap hari. Pemberdayaan wanita dalam hal ini emansipasi wanita, Berbicara tentang emansipasi, sosok Radeng Ajeng Kartini merupakan contoh yang nyata. Usahanya dalam memperjuangkan hak wanita untuk mendapatkan pendidikan setinggi-tingginya dan diberikan kesempatan yang sama untuk menerapkan ilmu yang dimilikinya agar tidak direndahkan derajatnya membuat Kartini dikenal sebagai penggerak emansipasi wanita.

Seiring dengan perkembangan zaman, semakin banyak emansipasi wanita yang sudah mulai bisa dirasakan. Hanya saja kebanyakan wanita masih belum paham bagaimana cara menerapkannya dengan langkah nyata. Dalam bidang ekonomi, manusia diharapkan dapat memperoleh atau menciptakan lapangan kerja yang produktif dan mampu memberikan jaminan bagi perekonomian setiap rumah tangga. Seorang kepala rumah tangga memikul tanggung jawab besar untuk mewujudkan hal tersebut agar dapat memberikan nafkah bagi keluarganya. Dalam suatu situasi dan kondisi, ibu-ibu rumah tangga seyogyanya dapat pula berperan secara aktif untuk mencari penghasilan tambahan agar tugas sebagai kepala rumah tangga menjadi ringan dengan tidak melupakan tanggung jawabnya sebagai tokoh sentral dalam mengurus segala sesuatu yang menjadi tanggung jawabnya. 
Di Rt 21 Rw 08, ibu - ibu rumah tangga nya rata-rata bekerja secara mandiri untuk mencukupi kebutuhan keluarganya.
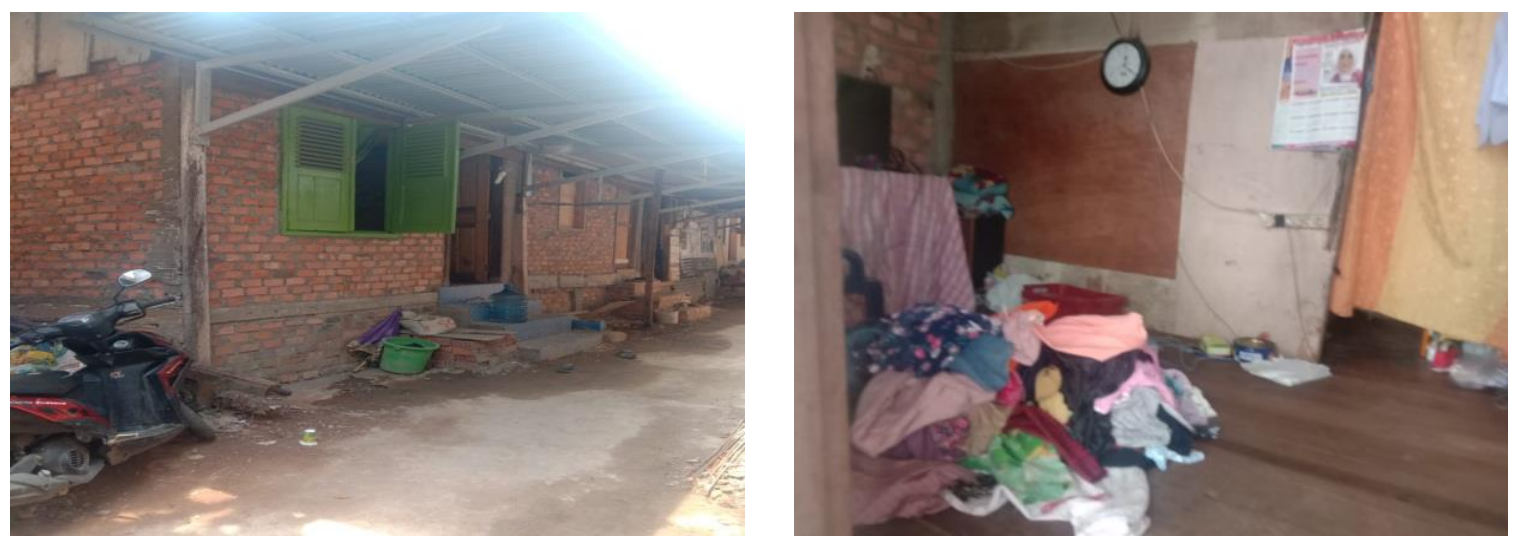

Gambar 1. Rumah mitra

Mereka berjuang keras dalam mencukupi kebutuhannya. Dengan cara mengambil upahan cucian pakain kotor ke pelanggan dimana pelanggang tersebut adalah pasien - pasien rumah sakit Muhammad husein Palembang. Dalam pekerjaanya mereka sudah menjalankan usahanya selama 1,5 cuci pakaiann, sejak cuci pakaiann 2016, Bahan baku yang dibutuhkan adalah deterjen, farfum pakaian, pelican pakaian.

Tabel 1. Biaya Produksi, Penjualan,dan Keuntungan Produk Cuci pakaian

\begin{tabular}{|c|c|}
\hline Keterangan & Jumlah \\
\hline Deterjen & 40.000 \\
\hline Pewangi & 40.000 \\
\hline Total Biaya Produksi & 80.000 \\
\hline Jumlah Penjualan & 210.000 \\
\hline Keuntungan & 130.000 \\
\hline
\end{tabular}

Sumber : Hasil Wawancara Lapangan

Dari hasil wawancara di lapangan, selama menjalankan usaha tersebut menghadapi berbagai masalah diantaranya masih rendahnnya kuantitas produksi, rendahnya kualitas produk. Permasalahan tersebut tentu saja mempengaruhi kinerja usaha selama ini dan secara tidak langsung berpengaruh pula terhadap pendapatan keluarga. Oleh karena itu penulis melalui Program Ipteks Bagi Masyarakat (PKMSS) cuci pakaiann 2016 mencoba untuk membina, mendampingi, dan memberdayakan kedua mitra agar mampu mengatasi permasalahan tersebut dan dapat mengembangkan usahanya menjadi lebih baik

\subsection{Metode Pelaksanaan}

Sifat dari kegiatan PKMS adalah berbasis kebutuhan dan kemampuan mitra sasaran, maka metode yang digunakan dalam pelaksanaannya adalah dengan pendekatan partisipatif (partisipative approach) dimana mitra sasaran terlibat langsung baik dalam FGD (focus group discussion), wawancara, berkonsultasi, dan menentukan keputusan tindakan. Pelaksanaan kegiatan melalui 4 tahapan berikut :

1. Tahap Persiapan dan Perencanaan

Tim pelaksana melakukan persiapan dan perencanaan dalam bentuk :

a. Sosialisasi Implementasi PKMS

Pada tahap ini tim pelaksana akan memaparkan maksud dan tujuan, metode dan teknis pelaksanaan PKMS, serta melakukan FGD untuk menyepakati prioritas masalah yang dihadapi dan alternatif solusinya.

b. Penyusunan Program Kegiatan

Tim pelaksana melakukan FGD dengan mitra untuk menentukan bentuk, waktu dan tempat 
pelaksanaan kegiatan. Program kegiatan meliputi penyuluhan,

2. Tahap Implementasi Kegiatan

Tim pelaksana akan memulai kegiatan sesuai dengan jadwal yang sudah ditentukan dan disepakati bersama dengan mitra. Kegiatan pelatihan menggunakan metode ceramah dan diskusi (tanya jawab) sedangkan penentuan keputusan lain berdasarkan hasil FGD dengan mitra.

3. Tahap Evaluasi dan Monitoring

Kegiatan dimonitoring oleh tim sendiri dan melihat apa saja kendala dan masalah yang muncul di lapangan. Kemudian dilakukan evaluasi apabila memang muncul kendal dan masalah untuk selanjutnya dicarikan solusi agar kegiatan tetap berlangsung dengan baik sesuai yang diharapkan. Metode yang digunakan adalah FGD dengan Mitra.

4. Tahap Refleksi

Refleksi terhadap hasil pelaksanaan kegiatan dilakukan dengan tujuan untuk memperoleh umpan balik terhadap manfaat maupun dampak yang dirasakan mitra setelah dilakukan pelatihan dan pembinaan. Hal ini diperlukan sebagai masukan bagi pelaksanaan kegiatan serupa di masa datang. Metode yang digunakan adalah F.

\section{HASIL DAN PEMBAHASAN}

\subsection{Kegiatan yang Telah Dilaksanakan}

Program Kemitraan Masyarakat Stimulus (PKMSS) Laundry rumahan oleh ibu rumah tangga telah dilaksanakan dalam jangka waktu April - Juli 2019 atau kurang lebih selama 4 bulan. Beberapa kegiatan yang telah dilaksanakan meliputi kegiatan persiapan, pelatihan dan pendampingan. Selama program hibah PKMSS ini, tim dibantu oleh dua orang mahasiswa yaitu M Reza dan Renny. Kedua orang mahasiswa ini secara bergantian membantu melancarkan program PKMSS. Kegiatan yang sudah dilaksanakan dan hasil yang dicapai diuraikan singkat pada tabel di bawah ini:

Tabel 2. Kegiatan Yang Sudah dilaksanakan dan Hasil yang Dicapai

\begin{tabular}{|c|c|c|c|}
\hline NO & TANGGAL & KEGIATAN & HASIL YANG DICAPAI \\
\hline 1 & 10 April 2019 & $\begin{array}{l}\text { Rapat Persiapan Kegiatan } \\
\text { Pelaksanaan }\end{array}$ & $\begin{array}{l}\text { Tim pelaksana bersama dengan para narasumber } \\
\text { menyusun rencana jadwal sosialisasi, pelatihan } \\
\text { dan pengadaaan alat penunjang produksi dan } \\
\text { media promosi }\end{array}$ \\
\hline 2 & 12 April 2019 & $\begin{array}{l}\text { Sosialisasi Pelaksanaan } \\
\text { Kegiatan PKMS }\end{array}$ & $\begin{array}{l}\text { Disepakatinya jadwal, lokasi, pengadaan } \\
\text { penunjang produksi, media promosi } \\
\text { partisipasi mitra dalam kegiatan PKMS. }\end{array}$ \\
\hline 3 & 13 April 2019 & $\begin{array}{l}\text { Pelatihan Pembuatan Blog dan } \\
\text { medsos }\end{array}$ & $\begin{array}{l}\text { a. Mitra mengetahui pengetahuan mengenai } \\
\text { strategi pemasaran dan promosi } \\
\text { b. Mitra mengetahui manfaat media sosial } \\
\text { sebagai sarana penjualan dan promosi } \\
\text { c. Mitra menggunakan media sosial seperti } \\
\text { blog, instagram dan saphira sebagai media } \\
\text { pemasaran online }\end{array}$ \\
\hline 4 & 16 April 2019 & $\begin{array}{l}\text { Pelatihan Pengembangan Jiwa } \\
\text { Kewirausahaan }\end{array}$ & $\begin{array}{l}\text { Mitra memperoleh pengetahuan mengenai cara } \\
\text { mengembangkan bisnis kewirausahaan }\end{array}$ \\
\hline 5 & 19 Juni 2019 & $\begin{array}{l}\text { Pelatihan Pembuatan Stok } \\
\text { Barang Pada Usaha Laundry } \\
\text { Ibu Rumah Tangga }\end{array}$ & $\begin{array}{l}\text { a. Mitra memperoleh pengetahuan cara } \\
\text { menghitung stok barang dan persediaan } \\
\text { yang dibutuhkan pada saat produksi, } \\
\text { sehingga bisa memisahkan anggaran dana } \\
\text { untuk persediaan tersebut. } \\
\text { b. Mitra mengetahui cara membuat buku hutang, } \\
\text { piutang dan buku stok }\end{array}$ \\
\hline
\end{tabular}




\begin{tabular}{|c|c|c|c|}
\hline 6 & 20 Juni 2019 & $\begin{array}{l}\text { Pelatihan membuat laporan } \\
\text { keuangan dengan Ms Excel }\end{array}$ & $\begin{array}{l}\text { a. Mitra mengetahui manfaat membuat } \\
\text { pembukuan } \\
\text { b. Mitra mengetahui cara membuat } \\
\text { pembukuan kas }\end{array}$ \\
\hline 7 & 24 Juni 2019 & $\begin{array}{l}\text { Pelatihan Cara Mudah Packing } \\
\text { Pakaian Laundry Pada Usaha } \\
\text { Ibu Rumah Tangga }\end{array}$ & $\begin{array}{l}\text { Mitra memperoleh bagaimana baju dengan baik } \\
\text { dan rapi. Cara mempacking. }\end{array}$ \\
\hline 8 & 25 Juni 2019 & $\begin{array}{c}\text { Pelatihan } \begin{array}{c}\text { Logo untuk Usaha } \\
\text { Laundry }\end{array}\end{array}$ & $\begin{array}{l}\text { Mitra diajarkan cara membuat logo usaha prouksi } \\
\text { sehingga lebih meningkatkan nilai jual ke } \\
\text { pelanggan }\end{array}$ \\
\hline 9 & 2 Juli 2019 & $\begin{array}{c}\text { Sosialisasi ke mitra tentang alat } \\
\text { yang akan digunakan }\end{array}$ & $\begin{array}{l}\text { Mitra menjelaskan kebutuhan digunakan Mesin } \\
\text { yang akan }\end{array}$ \\
\hline 10 & 5 Juli 2019 & $\begin{array}{c}\text { Penyerahan mesin air untuk } \\
\text { memperlancar usaha laundry }\end{array}$ & $\begin{array}{l}\text { Mitra mendapatkan bantuan berupa alat mesin air } \\
\text { untuk memperlancar usaha produksi mitra }\end{array}$ \\
\hline 11 & 16 Juli 2019 & $\begin{array}{l}\text { Penyerahan media promosi } \\
\text { berupa kantong plastik } \\
\text { kemasan bermerek usaha }\end{array}$ & $\begin{array}{l}\text { a. Mitra menerima kantong plastik kemasan } \\
\text { bermerek usaha } \\
\text { b. Mitra menggunakannya }\end{array}$ \\
\hline 12 & 14 Juli 2019 & Menyerahkan alat ke mitra & $\begin{array}{l}\text { a. Mitra menerima alat produksi } \\
\text { b. Mitra mendapat pengarahan cara } \\
\text { menggunakan alat produksi } \\
\text { c. Mitra menggunakan alat produksi }\end{array}$ \\
\hline 13 & 16 Juli 2019 & $\begin{array}{l}\text { Pemasangan dan penyerahan } \\
\text { media promosi berupa cetak } \\
\text { nama banner usaha }\end{array}$ & Mitra menerima cetak baner usaha \\
\hline 14 & $\begin{array}{l}13 \text { Agustus } \\
2019\end{array}$ & $\begin{array}{l}\text { Pengiriman artikel Pengabdian } \\
\text { Pada Masyakat ke Poltek Unsri }\end{array}$ & $\begin{array}{l}\text { Full Paper telah diterima oleh Ilin Institute, tinggal } \\
\text { menunggu konfirmasi }\end{array}$ \\
\hline
\end{tabular}

Untuk lebih jelasnya, berikut semua kegiatan dan hasil yang sudah dicapaidalam kegiatan PKMS 2017 diuraikan sebagai berikut :

1. Rapat Persiapan Pelaksanaan Kegiatan

Rapat dilaksanakan pada tanggal 12 April 2019 bertempat di Kampus STMIK MDP yang dihadiri oleh tim pelaksana hibah PKMSS dan para narasumber yang akan terlibat di kegiatan PKMS. Rapat bertujuan untuk membicarakan rencana pelaksanaan pelatihan-pelatihan yang akan diberikan kepada mitra, jadwal dan tempat pelaksanaan serta kebutuhan apa saja yang diperlukan untuk menunjang pelatihan tersebut. Hasil rapat ini akan disosialisasikan kepada mitra.

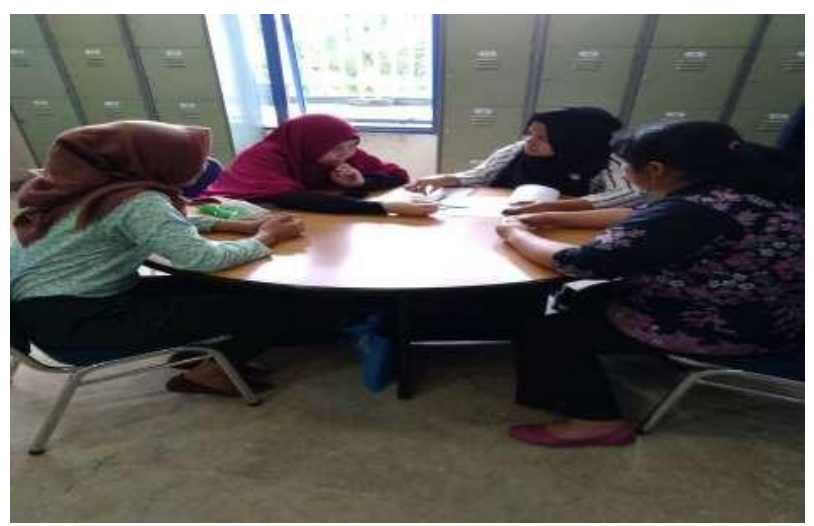

Gambar 2. Rapat Persiapan Kegiatan Hibah PKMS Sosialisasi Pelaksanaan Kegiatan PKMS 
Pada hari Jum'at, 12 April 2019 dilaksanakan sosialisasi kegiatan PKMS bertempat di tempat tetangga rumah mitra yaitu ibu Lenny. Tujuan dari kegiatan ini adalah untuk mensosialisasikan rencana pelaksanaan kegiatan PKMS kepada mitra diantaranya : menjelaskan jenis kegiatan, menentukan jadwal kegiatan, lokasi kegiatan, materi pelatihan, dan metode pelatihan. Selain itu juga didiskusikan tentang peralatan penunjang produksi dan media promosi yang akan diberikan kepada mitra.

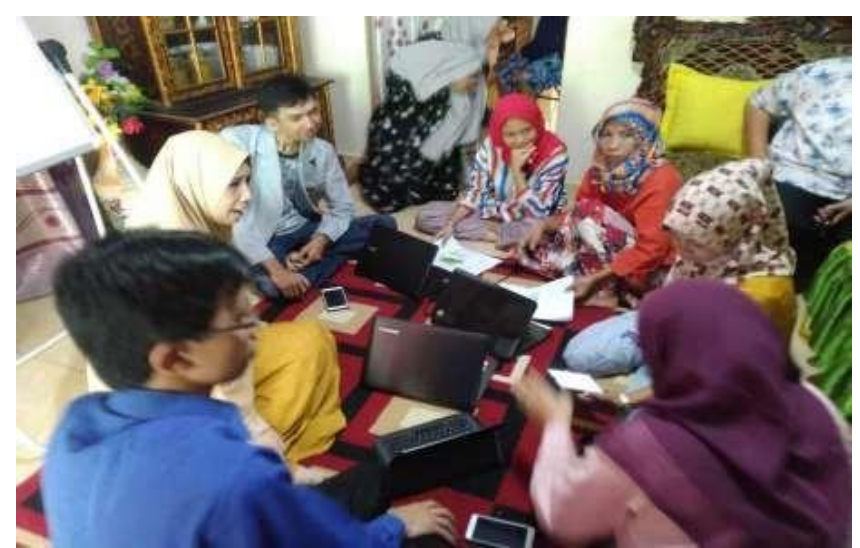

Gambar 3. Sosialisasi Kegiatan PKMS ke Mitra

2. Pelatihan Pembuatan Medsos dan Blog

Pelatihan ini dilaksanakan pada hari Sabtu, 13 April 2019 Sebagai narasumber untuk pelatihan medsos dan blog adalah Ibu Desy Iba dan dibantu oleh Ibu Mulyati dan Pak Dorie. Tujuan dari kegiatan ini adalah:

a. Memberikan pemahaman tentang pentingnya promosi bagi usaha kecil dan enengah

b. Memberikan keterampilan penggunaan teknologi sebagai sarana promosi

c. Memberikan keterampilan cara membuat fanspage dan blog

Pelatihan selanjutnya dengan membuat blog bisnis. Narasumber memberikan pelatihan cara-cara membuat blog dengan menggunakan wordpress. Blog yang ramai pengunjung tentu akan bisa dijadikan sebagai tempat untuk melakukan promosi produk. Jika blog yang dikelola mampu mendatangkan visitor yang ramai serta memberikan informasi yang menarik dan bermanfaat untuk pengunjung, sudah tentu nama blog semakin dikenal oleh banyak orang. Apalagi jika nama blog merupakan nama brand atau merek sesuai dengan produk / jasa yang dijalankanmitra.

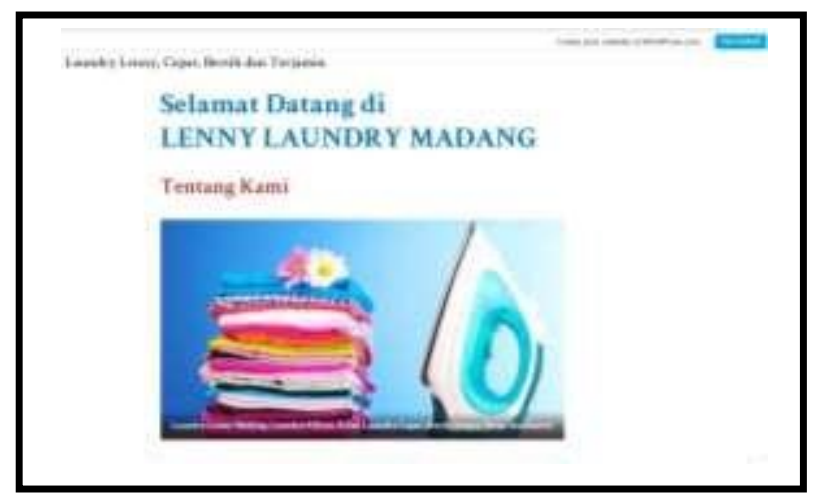

Gambar 4. Pelatihan Blog

3. Pelatihan Pengembangan Jiwa Kewirausahaan

Pelatihan ini berrtujuan untuk membangun jiwa kewirausahaan bagi mitra guna lebih menumbuhkan lagi jiwa enterpriner nya dalam menjalankan usahanya dan bertujuan membuat rasa berani dan kepecayaan diri dalam mengembangkan usaha tersebut. 



Gambar 5. Pelatihan Pengembangan Jiwa Kewirausahaan

4. Pelatihan Stok Barang

Dilaksanakan pada hari Sabtu, 19 Juni 2019 pukul 13.00 sampai dengan pukul 15.00. Pelatihan Membuat Laporan Biaya Produksi juga dilaksanakan pada hari yang sama. Setelah pelatihan strategi pengembangan usaha mitra diajarkan cara membuat perhitungan dan pelaporan harga pokok produksi dan stok barang. Mereka hanya memperkirakan saja biaya produksi untuk membuat hasil cucian bersih dan rapi dari biaya yang mereka keluarkan untuk membeli bahan baku sedangkan biayabiaya lain seperti biaya ongkos angkut (transportasi), biaya tenaga kerja dan biaya lain-lain belum mereka perhitungkan. Sehingga hasil perhitungan biaya produksinya lebih kecil dan secara tidak langsung juga akan mempengaruhi harga jual. Dengan adanya pelatihan ini mitra dapat menentukan dan menghitung kembali biaya produksinya dengan lebih baik dan tidak berdasarkan pada taksiran saja.

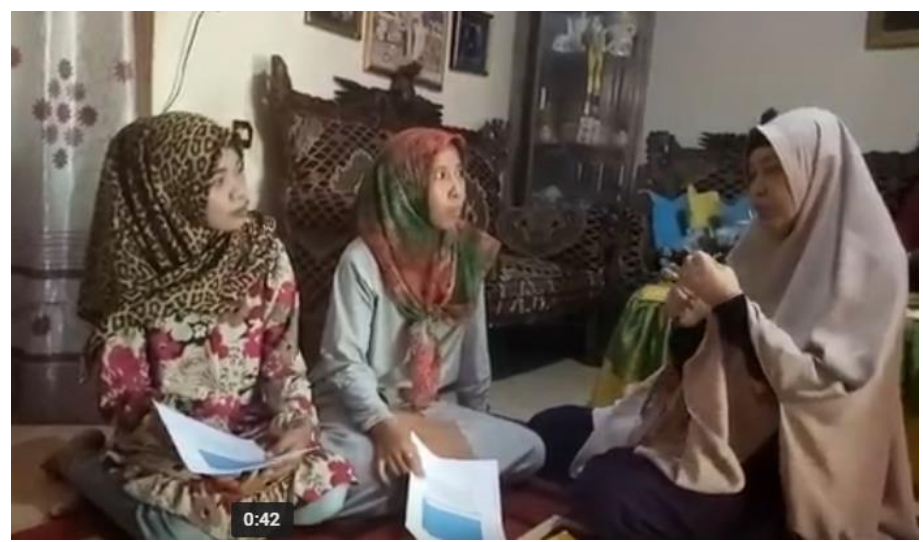

Gambar 6. Pelatihan Pembuatan Stok Barang

5. Pemasangan dan Penyerahan Alat Penunjang Produksi

Untuk mengatasi permasalahan produksi yang dihadapi oleh kedua mitra, tim pelaksana hibah PKMS 2019 berupaya untuk membantu mitra dalam pengadaan alat penunjang produksi berupa mesin jahit khusus konveksi yang mempunyai kemampuan untuk menjahit lebih cepat dan lebih banyak serta dapat juga digunakan untuk menjahit bahan- bahan tebal seperti tikar purun. Penyerahan semua peralatan penunjang produksi dilaksanakan pada tanggal 14 Juli 2019 di rumah mitra. Dalam penyerahan peralatan tersebut dilakukan pula penandatanganan berita acara penerimaan peralatan oleh mitra. 


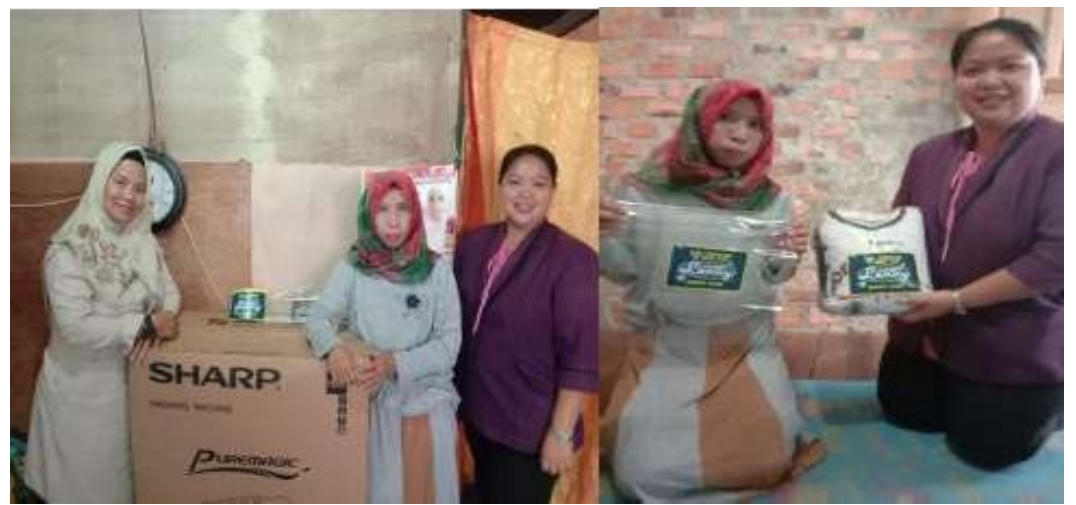

Gambar 7. Penyerahan Alat Penunjang Produksi di Mitra

6. Pelatihan membuat pembukuan sederhana untuk UMKM

Pelatihan ini bertujuan untuk mendisiplinkan mitra dalam membuat catatan keuangan dengan ms excel Karena hampir sebagian besar UMKM tidak mempunyai catatan keuangan usahanya. Mereka tidak pernah mencatat berapa uang yang masuk, berapa uang yang keluar, berapa catatan hutang dan piutang. Bahkan ada juga yang tidak mempunyai catatan stock barang. Dengan adanya pelatihan ini mitra diajarkan cara membuat catatan keuangan sederhana mulai dari membuat catatan kas, kemudian mendata jumlah hutang baik hutang dari keluarga sendiri ataupun hutang dari pihak lain, dan mendata tagihan kepada pihak lain. Sebagai narasumber pada pelatihan ini adalah Bapak Daniel Udjulawa dan dibantu oleh bapak iis pradesan dan ibu lisa Amelia.

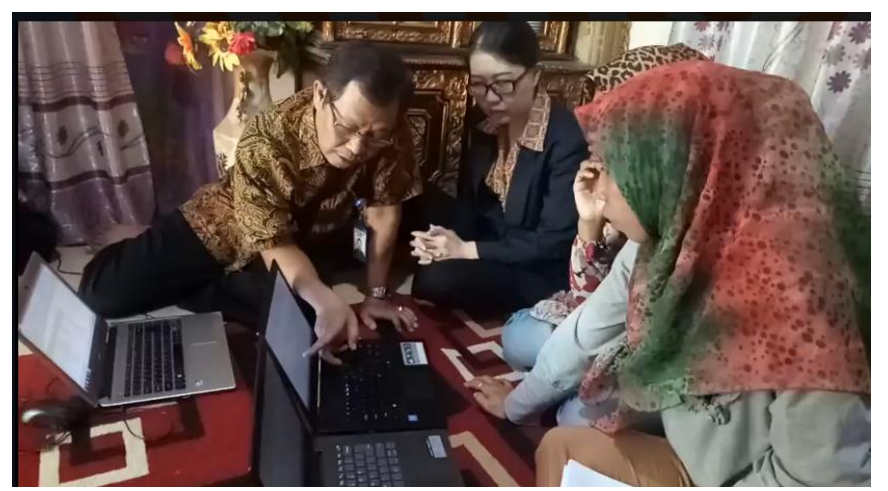

Gambar 8. Pelatihan Pembukuan Sederhana dengan Microsoft Excel

\section{Penyerahan Media Promosi Kantong Plastik Kemasan Berlogo}

Pada tanggal 16 Juli 2019 dilakukan penyerahan kantong plastik kemasan berlogo mitra. Pada saat penyerahan, dilakukan pula penandatanganan berita acara penyerahan dan penerimaan alat dan media promosi.
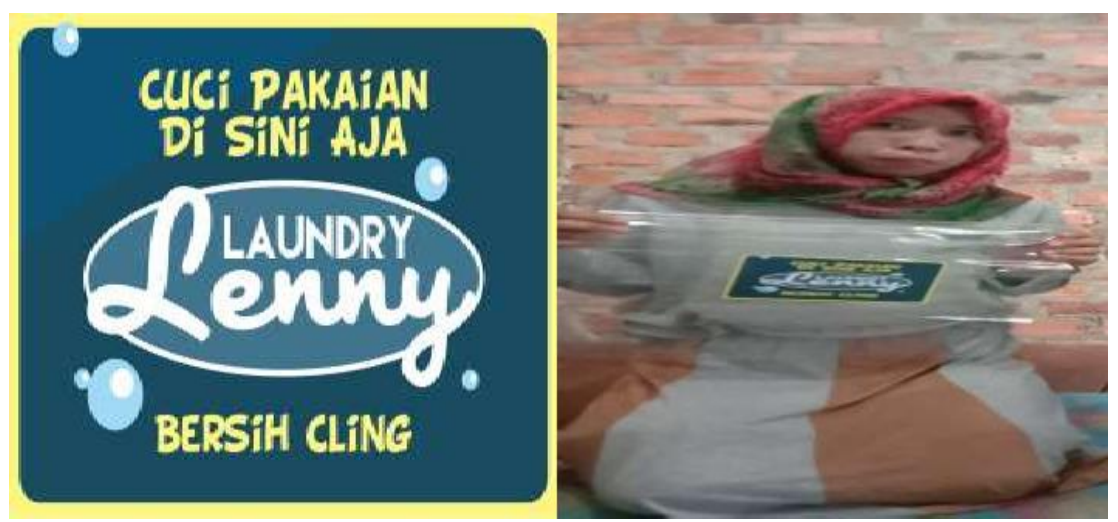

Gambar 9. Logo Dikemasan Bungkus Plastik 


\section{KESIMPULAN DAN SARAN}

UMKM merupakan bagian dari industri kreatif, yang merupakan suatu kegiatan usaha yang fokus pada kreasi dan inovasi.Jumlah Pelaku UMKM yang tersebar di wilayah Indonesia sangat banyak. Secara akumulatif usaha tersebut mampu menopang perekonomian Indonesia. Namun sebaliknya, secara individul masih banyak pelaku UMKM khususnya usaha mikro yang masih menghadapi berbagai masalah dan belum tersentuh pembinaan dan pendampingan terutama dari pemerintah.

Dalam program PKMS ini, pembinaan dan pemberdayaan yang dilakukan terhadap kedua mitra binaan tidak hanya dalam bentuk pembekalan pengetahuan dan keterampilan melalui pelatihan, tetapi juga pemberian peralatan penunjang produksi dan pemasaran, serta penerapan pembukuan usaha dan menghitung biaya produksi. Pembekalan pengetahuan dan keterampilan yang diberikan meliputi : cara membuat blog , cara menghitung biaya produksi, dan cara membuat pembukuan sederhana untuk mitra. Semua materi pelatihan dan peralatan penunjang diberikan sesuai dengan kondisi nyata, masalah, dan kebutuhan mitra binaan. Semua materi pelatihan belum pernah peroleh sebelumnya, sehingga direspon dengan baik dan diterima dengan antusias. Dalam hasil wawancara didapat bahwa mitra merasakan perubahan dan perkembangan omset yang mereka terima karean dalam hal ini mitra mampu menerima cucian lebih banyak lagi dalam menjalankan usahanya karena ditunjang dengan peralatan yang bertamnah yaitu mesin cuci dan mesin air. Manfaat yang dirasakan dalam jangka pendek adalah dalam bentuk peningkatan kapasitas atau kuantitas produksi maupun omzet penjualan (50\%-80\%). Sedangkan pada masa yang akan datang, diharapkan mitra dapat memperluas wilayah pemasaran produk, sehingga usaha dapat terus berkembang.

Pelaksanaan kegiatan PKMS 2019 dapat berjalan dengan lancar dana yang diberikan oleh Dikti dapat diserap dengan baik oleh kedua mitra melalui pemberian pelatihan, pembinaaan dan pendampingan, pemberian alat penunjang produksi serta pemberian atribut promosi. Untuk masa yang akan datang diharapkan kegiatan ini dapat berjalan terus sehingga dapat mengatasi permasalahan yang dihadapi oleh pelaku masyarakat khusunya dalam membantu perekonmian dalam keluarga.

\section{UCAPAN TERIMA KASIH}

Ucapan terima kasih untuk menristekdikti, dan kampus STMIK MDP dan semua pihak yang telah membantu dalam kegiatan ini.

\section{DAFTAR PUSTAKA}

Evans, Liana. 2009. Social Media Marketing: Strategies for Engaging in Facebook, Twitter \& Other Social Media. Princeton: University Press

Kasih, Yulizar dan Rini Aprilia. 2013."The Competitiveness of Indonesian Micro- Small-Medium Enterprises (MSMEs) Facing ASEAN Economic Community (AEC) in 2015", Proceeding, ICEISM 2014, p.159.

Kuncoro, Mudrajad. 2013. "Usaha Kecil di Indonesia : Profil, Masalah, dan Strategi Pengembang" . www.mudrajad.com (diakses 26/12/2018).

Kurniawan, Aris. 2019. Pengertian Media Sosial - Sejarah, Fungsi, Peran, Jenis, Ciri, Pertumbuhan, Dampak, Para Ahli. https://www.gurupendidikan.co.id/pengertian-media-sosial/ (diakses 12 April 2019). 